\title{
PENGARUH KOMPENSASI, PENGALAMAN KERJA DAN \\ KOMITMEN ORGANISASI TERHADAP KINERJA \\ PEGAWAI NEGERI SIPIL (PNS) PADA DINAS \\ PEKERJAAN UMUM DAERAH KABUPATEN SIGI
}

\author{
Nasrula Kaiyeli \\ nasrulahilyas@gmail.com
}

(Dosen Fakultas Ekonomi Universitas Alkhairaat)

\begin{abstract}
ABSTRAK
Adapun tujuan penelitian ini yaitu: 1) Untuk menguji dan menganalisis pengaruh kompensasi, pengalaman kerja dan komitmen organisasi terhadap kinerja Pegawai Negeri Sipil (PNS) pada Dinas Pekerjaan Umum Daerah Kabupaten Sigi; 2) Untuk menguji dan menganalisis pengaruh kompensasi terhadap kinerja Pegawai Negeri Sipil (PNS); 3) Untuk menguji dan menganalisis pengaruh pengalaman kerja terhadap kinerja Pegawai Negeri Sipil (PNS); dan 4) Untuk menguji dan menganalisis pengaruh komitmen organisasi terhadap kinerja Pegawai Negeri Sipil (PNS). Penelitian ini menggunakan jenis penelitian deskriptif dan kausal (causality) dalam menjelaskan pengaruh antar variabel kompensasi, pengalaman kerja, komitmen organisasi dan kinerja pegawai yang melibatkan 56 orang sampel dengan teknik sampling jenuh (sensus). Berdasarkan hasil pengujian dengan menggunakan analisis regresi linear berganda, disimpulkan: 1) Kompensasi, pengalaman kerja dan komitmen organisasi secara simultan berpengaruh positif dan signifikan terhadap kinerja PNS pada Dinas Pekerjaan Umum Daerah Kabupaten Sigi; 2) Kompensasi berpengaruh positif dan signifikan terhadap kinerja PNS; 3) Pengalaman kerja berpengaruh positif dan signifikan terhadap kinerja PNS; dan 4) Komitmen organisasi berpengaruh positif dan signifikan terhadap kinerja PNS.
\end{abstract}

Kata Kunci: Kompensasi, Pengalaman Kerja, Komitmen Organisasi, Kinerja.

\section{LATAR BELAKANG}

Kompensasi dapat meningkatkan kinerja karyawan. Oleh karena itu perhatian organisasi atau perusahaan terhadap pengaturan kompensasi secara rasional dan adil sangat diperlukan. Bila karyawan memandang pemberian kompensasi tidak memadai kinerja mereka cenderung akan menurun. Samsudin (2006:187) Kompensasi adalah segala sesuatu yang diterima para karyawan sebagai balas jasa atas kerja mereka, dan kompensasi itu sendiri dapat dibagi menjadi dua yaitu kompensasi langsung dan tak langsung. Menurut Ruky (2001:10) kompensasi langsung merupakan imbalan jasa kepada pegawai yang diterima secara langsung, rutin atau periodik karena yang bersangkutan telah memberikan bantuan/sumbangan untuk mencapai tujuan organisasi, dan kompensasi langsung meliputi gaji, bonus/ insentif, komisi. Selain kompensasi langsung, kompensasi tak langsung juga mempunyai peranan yang tak kalah pentingnya untuk meningkatkan kinerja karyawan. Pengalaman kerja pegawai mencerminkan tingkat penguasaan pengetahuan dan keterampilan yang dimiliki seorang pegawai dalam bekerja yang dapat diukur dari masa kerja dan jenis pekerjaan yang pernah dikerjakan pegawai.

Ranupandojo (1984 :71) Pengalaman kerja adalah ukuran tentang lama waktu atau masa kerja yang telah ditempuh seseorang dapat memahami tugas-tugas suatu pekerjaan dan telah melaksanakan dengan baik.

Pengukuran pengalaman kerja sebagai sarana untuk menganalisa dan mendorong efisiensi dalam pelaksanaan tugas pekerjaan. Beberapa hal yang digunakan untuk mengukur pengalaman kerja seseorang adalah :

1. Gerakannya mantap dan lancar

Setiap karyawan yang berpengalaman akan melakukan gerakan yang mantap dalam bekerja tanpa disertai keraguan. 
2. Gerakannya berirama

Artinya terciptanya dari kebiasaan dalam melakukan pekerjaan sehari-hari

3. Lebih cepat menaggapi tanda-tanda

Artinya tanda-tanda seperti akan terjadi kecelakaan kerja

4. Dapat menduga akan timbulnya kesulitan sehingga lebih siap menghadapinya karena didukung oleh pengalaman kerja dimilikinya makaseorang pegawai yang berpengalaman dapat menduga akan adanya kesulitan dan siap menghadapinya.

5. Bekerja dengan tenang

Asri (1986:131) Seorang pegawai yang berpengalaman akan memiliki rasa percaya diri yang cukup besar.

Luthans (2006:249) Komitmen organisasi merupakan sikap yang merefleksikan loyalitas karyawan pada organisasi dan proses berkelanjutan di mana anggota organisasi mengekspresikan perhatiannya terhadap organisasi dan keberhasilan serta kemajuan yang berkelanjutan. Komitmen organisasi menurut Robbins and Judges (2011) komitmen organisasional mendefinisikan sebagai kekuatan yang bersifat relatif dari individu dalam mengidentifikasikan keterlibatan dirinya kedalam bagian organisasi, yang dicirikan oleh penerimaan nilai dan tujuan organisasi, kesediaan berusaha demi organisasi dan keinginan mempertahankan keanggotaan dalam organisasi.

$$
\text { Allen dan Meyer }
$$

mengidentifikasikan tiga tema yang berbeda dalam pendefinisian komitmen, yaitu affective commitment atau komitmen afektif adalah komitmen sebagai suatu ikatan atau keterlibatan emosi dalam mengidentifikasi dan terlibat dalam organisasi, continuance commitment menunjukkan keputusan tetap mempertahankan keanggotaan dalam organisasi berdasarkan kalkulasi biaya yang harusditanggung (perceived cost) jika memutuskan keluar dari organisasi, normative commitment adalah perasaan karyawan untuk berkewajiban tetap bergabung dengan organisasi.

Menurut Rivai dan Ela (2011), kinerja merupakan perilaku nyata yang ditampilkan oleh setiap orang sebagai prestasi kerja yang dihasilkan oleh karyawan sesuai dengan perannya dalam perusahaan. Kinerja karyawan merupakan hal yang sangat penting bagi perusahaan dalam upaya mencapai tujuannya.

Berdasarkan pengertian di atas kinerja atau performance adalah hasil kerja yang dapat dicapai oleh seseorang atau kelompok orang dalam suatu organisasi, sesuai dengan wewenang dan tanggung jawab masing-masing, dalam rangka mencapai tujuan organisasi bersangkutan secara legal, tidak melanggar hukum dan sesuai dengan moral maupun etika. Tercapainya tujuan lembaga atau perusahaan hanya di mungkinkan karenanya para pelaku yang terdapat dalam organisasi lembaga atau perusahaan tersebut.

Berdasarkan uraian permasalahan yang dikemukakan di atas, maka penulis melakukan penelitian dengan judul "Pengaruh Kompensasi, Pengalaman Kerja dan Komitmen Organisasi Terhadap Kinerja Pegawai Negeri Sipil (PNS) Pada Dinas Pekerjaan Umum Daerah Kabupaten Sigi”.

1. Apakah kompensasi, pengalaman kerja dan komitmen organisasi secara simultan berpengaruh terhadap kinerja Pegawai Negeri Sipil (PNS) pada Dinas Pekerjaan Umum Daerah Kabupaten Sigi?

2. Apakah kompensasi berpengaruh terhadap kinerja Pegawai Negeri Sipil (PNS) pada Dinas Pekerjaan Umum Daerah Kabupaten Sigi?

3. Apakah pengalaman kerja berpengaruh terhadap kinerja Pegawai Negeri Sipil (PNS) pada Dinas Pekerjaan Umum Daerah Kabupaten Sigi?

4. Apakah komitmen organisasi berpengaruh terhadap kinerja Pegawai Negeri Sipil (PNS) pada Dinas Pekerjaan Umum Daerah Kabupaten Sigi?

\section{KAJIAN PUSTAKA \\ Kompensasi}

Kompensasi merupakan sesuatu yang diterima karyawan sebagai pengganti kontribusi jasa mereka pada perusahaan. Pemberian kompensasi merupakan salah satu pelaksanaan fungsi MSDM yang berhubungan dengan semua jenis pemberian penghargaan individual sebagai 
pertukaran dalam melakukan tugas keorganisasian. Kompensasi merupakan biaya utama atas keahlian atau pekerjaan dan kesetiaan dalam bisnis perusahaan pada abad ke-21.

Hasibuan (2005:35) mendefinisikan kompensasi sebagai :

Semua pendapatan yang berbentuk uang, barang langsung atau tidak langsung yang diterima karyawan sebagai imbalan atau jasa yang diberikan kepada perusahaan. Kompensasi berbentuk uang, artinya kompensasi dibayar dengan sejumlah uang kartal kepada karyawan.Kompensasi berbentuk barang, adalah kompensasi yang dibayar dengan barang.

Kompensasi adalah apa yang seorang pekerja terima sebagai balasan dari pekerjaan yang diberikannya. Baik upah per jam ataupun gaji periodik yang didesain dan dikelola oleh bagian personalia. William B. Werther dan Keith Davis (dalam Hasibuan, 2005 : 36).

Pendapat-pendapat yang dikemukakan oleh para ahli pada dasarnya adalah sama. Secara garis besar diterangkan melalui pendapat yang dikemukakan oleh Andrew E Sikula yang dikutip oleh Mangkunegara (2009:50), yang mengungkapkan bahwa proses administrasi upah atau gaji (kadang-kadang disebut kompensasi) melibatkan pertimbangan atau keseimbangan perhitungan.

Kompensasi merupakan sesuatu yang dipertimbangkan sebagai suatu yang sebanding. Dalam sistem administrasi kepegawaian, hadiah yang bersifat uang merupakan kompensasi yang diberikan kepada pegawai sebagai penghargaan dari pelayanan mereka. Bentuk-bentuk pemberian upah, bentuk upah dan gaji digunakan untuk mengatur pemberian keuangan antara majikan dan pegawainya.

\section{Jenis-Jenis Kompensasi}

Menurut Dessler (dikutip oleh Indriyatni, 2009 : 48) kompensasi mempunyai tiga komponen sebagai berikut :

1. Pembayaran uang secara langsung (direct financial payment) dalam bentuk gaji, dan intensif atau bonus/komisi.

2. Pembayaran tidak langsung (indirect payment) dalam bentuk tunjangan dan asuransi.

3. Ganjaran non finansial (non financial rewards) seperti jam kerja yang luwes dan kantor yang bergengsi.
Mondy et al., (1993) mengemukakan bentuk kompensasi dapat dikelompokkan adalah sebagai berikut :

a. Kompensasi Finansial.

1. Kompensasi finansial langsung (direct financial compensation).

Terdiri dari bayaran (pay) yang diperoleh seseorang dalam bentuk gaji, upah, bonus dan komisi.

2. Kompensasi finansial tidak langsung (indirect financial compensation).

Disebut juga dengan tunjangan (meliputi imbalan finansial yang tidak tercakup dalam kompensasi langsung).

b. Kompensasi Non Finansial (Non Financial Compentation).

Terdiri dari kepuasan yang diperoleh seseorang dari pekerjaan itu sendiri, atau dari lingkungan psikologis dan atau fisik dimana orang tersebut bekerja. Meliputi dari kepuasan yang didapat dari pelaksanaan tugas - tugas yang bermakna yang berhubungan dengan pekerjaan. Contoh bentuk kompensasi non finansial adalah tugas yang menarik, tantangan, tanggung jawab, peluang atau pengakuan, perasaan akan pencapaian, peluang akan promosi.

Tujuan Diadakan Pemberian Kompensasi

Menurut Hasibuan (2002:54), tujuan pemberian kompensasi(balas jasa) antara lain adalah:

1. Ikatan Kerja Sama

Dengan pemberian kompensasi terjalinlah ikatan kerja sama formal antara majikan dengan karyawan. Karyawan harus mengerjakan tugas-tugasnya dengan baik, sedangkan pengusaha/majikan wajib membayar kompensasisesuai dengan perjanjian yang disepakati.

2. Kepuasan Kerja

Dengan balas jasa, karyawan akan dapat memenuhi kebutuhan-kebutuhan fisik, status sosial, dan egoistiknya sehingga memperoleh kepuasan kerja dari jabatannya.

3. Pengadaan Efektif

Jika program kompensasi ditetapkan cukup besar, pengadaan karyawan yang qualified untuk perusahaan akan lebih mudah.

4. Motivasi

Jika balas jasa yang diberikan cukup besar, manajer akan mudah memotivasi bawahannya.

5. Stabilitas Karyawan 
Dengan program kompensasi atas prinsip adil dan layak serta eksternal konsistensi yang kompentatif maka stabilitas karyawan lebih terjamin karena turn-over relative kecil.

6. Disiplin

Dengan pemberian balas jasa yang cukup besar maka disiplin karyawan semakin baik. Mereka akan menyadari serta mentaati peraturan-peraturan yang berlaku.

7. Pengaruh Serikat Buruh

Dengan program kompensasi yang baik pengaruh serikat buruh dapat dihindarkan dan karyawan akan berkonsentrasi pada pekerjaannya.

8. Pengaruh Pemerintah

Jika program kompensasi sesuai dengan undang-undang perburuhan yang berlaku (seperti batas upah minimum) maka intervensi pemerintah dapat dihindarkan.

\section{Sistem Kompensasi}

Sistem pembayaran kompensasi yang umum diterapkan adalah:

1. Sistem Waktu

Dalam sistem waktu, besarnya kompensasi (gaji, upah) ditetapkan berdasarkanstandar waktu seperti jam, minggu, atau bulan.

2. Sistem Hasil (Output)

Dalam sistem hasil, besarnya kompensasi/upah ditetapkan atas kesatuan unit yang dihasilkan pekerja, seperti per potong, meter, liter, dan kilogram.

3. Sistem Borongan

Sistem borongan adalah suatu cara pengupahan yang penetapan besarnya jasa didasarkan atas volume pekerjaan dan lama mengerjakannya.

\section{Pengalaman Kerja}

Berdasarkan uraian tersebut maka dapat diketahui bahwa pengalaman kerja sangat membantu seseorang untuk mempersiapkan diri menghadapi pekerjaan yang mungkin sama dengan pekerjaan yang baru. Pengalaman kerja karyawan dalam melaksanakan tugas pada sebuah organisasi sangatlah penting peranannya. Seorang karyawan yang memiliki pengalaman kerja lebih banyak tentu akan lebih mengerti apa yang harus dilakukan ketika menghadapi masalah. Selain itu karyawan yang telah memiliki pengalaman kerja lebih banyak pasti akan lebih cepat dalam bekerja dan tidak harus beradaptasi dengan tugas yang dijalankan.
Ranupandojo (1984 :71) Pengalaman kerja adalah ukuran tentang lama waktu atau masa kerja yang telah ditempuh seseorang dapat memahami tugastugas suatu pekerjaan dan telah melaksanakan dengan baik. Selanjutnya Trijoko (1980: 82) Pengalamam kerja adalah pengetahuan atau keterampilan yang telah dilakukan selama beberapa waktu tertentu.

Pengukuran pengalaman kerja sebagai sarana untuk menganalisa dan mendorong efisiensi dalam pelaksanaan tugas pekerjaan. Beberapa hal yang digunakan untuk mengukur pengalaman kerja seseorang adalah :

1. Gerakannya mantap dan lancar

Setiap karyawan yang berpengalaman akan melakukan gerakan yang mantap dalam bekerja tanpa disertai keraguan.

2. Gerakannya berirama Artinya terciptanya dari kebiasaan dalam melakukan pekerjaan sehari-hari

3. Lebih cepat menaggapi tanda-tanda Artinya tanda-tanda seperti akan terjadi kecelakaan kerja

4. Dapat menduga akan timbulnya kesulitan sehingga lebih siap menghadapinya karena didukung oleh pengalaman kerja dimilikinya makaseorang pegawai yang berpengalaman dapat menduga akan adanya kesulitan dan siap menghadapinya.

5. Bekerja dengan tenang

Asri (1986:131) Seorang pegawai yang berpengalaman akan memiliki rasa percaya diri yang cukup besar.

\section{Faktor yang Mempengaruhi pengalaman} Kerja Karyawan

Beberapa factor lain mungkin juga berpengaruh dalam kondisi-kondisi tertentu, tetapi adalah tidak mungkin untuk menyatakan secara tepat semua factor yang dicari dalam diri karyawan potensial.

Beberapa faktor tersebut adalah :

1. Latar belakang pribadi, mencakup pendidikan, kursus, pelatihan, bekerja untuk menunujukan apa yang telah dilakukan seseorang diwaktu yang lalu.

2. Bakat dan minat, untuk memperkirakan minat dan kapasitas atau kemampuan seseorang.

3. Sikap dan kebutuhan (attitudes and needs) untuk meramalkan tanggung jawab dan wewenang seseorang. 
4. Kemampuan-kemampuan analitis dan manipulatif untuk mempelajari kemampuan penilaian dan penganalisaan.

5. Keterampilan dan kemampuan teknik, untuk menilai kemampuan dalam pelaksanaan aspekaspek teknik pekerjaan.

Foster (2001) menyatakan ada beberapa hal juga untuk menentukan berpengalaman tidaknya seorang karyawan yang sekaligus sebagai indikator pengalaman kerja yaitu:

a. Lama waktu / masa kerja

Ukuran tentang lama waktu atau masa kerja yang telah ditempuh seseorang dapat memahami tugas-tugas suatu pekerjaan dan telah melaksanakan dengan baik.

b. Tingkat pengetahuan dan keterampilan yang dimliki merujuk pada konsep, prinsip, prosedur, kebijakan, atau informasi lain yang dibutuhkan oleh karyawan. Pengetahuan juga mencakup kemampuan untuk memahami dan menerapkan informasi pada tanggung jawab pekerjaan. Sedangkan keterampilan merujuk pada kemampuan fisik yang dibutuhkan untuk mencapai atau menjalankan suatu tugas atau pekerjaan.

c. Penguasaan terhadap pekerjaan dan peralatan Tingkat penguasaan seseorang dalam pelaksanaan aspek-aspek teknik peralatan dan teknik pekerjaan.

Dari uraian tersebut dapat diketahui, bahwa seorang karyawan yang berpengalaman akan memiliki gerakan yang mantap dan lancar, gerakannya berirama, lebih cepat menanggapi tanda-tanda, dapat menduga akan timbulnya kesulitan sehingga lebih siap menghadapinya, dan bekerja dengan tenang serta dipengaruhi oleh factor lain yaitu : lama waktu / masa kerja seseorang, tingkat pengetahuan atau keterampilan yang telah dimiliki dan tingkat penguasaan terhadap pekerjaan dan peralatan. Oleh karena itu seorang karyawan yang pengalaman kerja adalah seseorang yang mempunyai kemampuan jasmani, memiliki pengetahuan dan keterampilan untuk bekerja serta tidak akan membahayakan bagi dirinya dalam bekerja.

\section{Komitmen Organisasi}

Luthans (2006) menyatakan bahwa komitmen organisasi adalah sikap yang merefleksikan loyalitas karyawan pada organisasi dan proses berkelanjutan di mana anggota organisasi mengekspresikan perhatiannya terhadap organisasi dan keberhasilan serta kemajuan yang berkelanjutan.

Komitmen organisasi menurut Gibson, et. Al (1997) dalam Hakim (2006) adalah identifikasi rasa, keterlibatan loyalitas yang ditampakkan oleh pekerja terhadap organisasinya atau unit organisasi. Komitmen organisasi ditunjukkan dalam sikap penerimaan, keyakinan yang kuat terhadap nilai-nilai dan tujuan-tujuan sebuah organisasi demi tercapainya tujuan organisasi.

Komitmen seseorang terhadap organisasi melibatkan tiga sikap:

1. Identifikasi dengan tujuan organisasi,

2. Perasaan keterlibatan dalam tugas-tugas organisasi, dan

3. Perasaan loyalitas terhadap organisasi.

Davis dan Newtrom (1998) dalam Kusjainah (2004) menyatakan bahwa komitmen karyawan terhadap organisasi adalah tingkat kemauan karyawan untuk mengidentifikasi dirinya pada organisasi dan keinginan untuk melanjutkan partisipasi aktif dalam organisasi tersebut.

Robbins S., \& Judge. (2011) Komitmen organisasional didefinisikan sebagai "The degree to which an employee identifies with aparticular organization and its goals, and wishes tomaintain membership in the organization". Cherrington (1994) Komitmen organisasi adalah suatu nilai personal, dimana seringkali mengacupada loyalitas terhadap perusahaan atau komitmen terhadap perusahaan.

Menurut Mowday, Porter dan Steers dalam Luthans (1995) dikatakan bahwa komitmen organisasi terdiri dari tiga faktor, yaitu :

1. Keinginan yang kuat untuk tetap menjadi anggota organisasi

2. Kemauan yang besar untuk berusaha bagi organisasi

3. Kepercayaan yang kuat dan penerimaan terhadap nilai dan tujuan organisasi.

Ketiga karakteristik ini menyatakan bahwa komitmen organisasi melibatkan lebih dari sekedar loyalitas yang pasif terhadap organisasi. Hal ini melibatkan suatu hubungan yang aktif dengan organisasi, dimana para karyawan mempunyai kemampuan untuk memberikan diri mereka dan membuat suatu kontribusi personal untuk membantu organisasi mencapai kesukesan. Selanjutnya, Porter et al. (1973) dalam Tobing (2009) mendefinisikan komitmen organisasional sebagai kekuatan relatif individu terhadap suatu 
organisasi dan keterlibatannya dalam organisasi tertentu, yang dicirikan oleh tiga faktor psikologis: (1) Keinginanyang kuat untuk tetap menjadi anggota organisasi tertentu, (2) Keinginan untuk berusaha sekuat tenaga demi organisasi dan (3) Kepercayaan yang pasti dan penerimaan terhadap nilai- nilai dan tujuan organisasi.

\section{Bentuk Komitmen Organisasi}

Dalam review mereka tentang literaturliteratur mengenai komitmen organisasi, Allen dan Meyer ( 1991 ) mengidentifikasikan tiga tema yang berbeda dalam pendefinisian komitmen, yaitu affective commitment atau komitmen afektif adalah komitmen sebagai suatu ikatan atau keterlibatan emosi dalam mengidentifikasi dan terlibat dalam organisasi, continuance commitment menunjukkan keputusan tetap mempertahankan keanggotaan dalam organisasi berdasarkan kalkulasi biaya yang harus ditanggung ( perceived cost) jika memutuskan keluar dari organisasi, normative commitment adalah perasaan karyawan untuk berkewajiban tetap bergabung dengan organisasi. Oleh Allen dan Meyer (1991:110) ketiga bentuk komitmen ini disebut sebagai :

a. Affective commitment, didefinisikan sebagai sampai derajad manakah seorang individu terikat secara psikologis pada organisasi yang mempekerjakan melalui perasaan seperti loyalitas, terikat dan sepakat dengan tujuan organisasi. Dengan demikian, komitmen afektif seorang individu berhubungan dengan ikatan emosional atau identifikasi individu tersebut dengan organisasi.

b. Continuance commitment, mengacu pada suatu kesadaran tentang biaya yang diasosiasikan dengan meninggalkan organisasi. Kontinuen komitmen adalah suatu keadaan dimana karyawan merasa membutuhkan untuk tetap tinggal, dimana mereka berfikir bahwa meninggalkan perusahaan akan sangat merugikan bagi mereka. Dengan kata lain individu dengan komitmen yang tinggi akan bertahan dalam organisasi karena mereka perlu akan hal itu.

c. Normative commitment, adalah suatu perasaan dari karyawan tetang kewajiban untuk bertahan dalam organisasi. Dalam hal ini menurut Brown dan Gaylor (2002) komitmen normatif dikarakterisasikan dengan keyakinan dari karyawan bahwa dia berkewajiban untuk tinggal/bertahan dalam suatu organisasi tertentu karena suatu loyalitas personal.
Dengan kata lain karyawan dengan komitmen normatif yang tinggiakan bertahan dalam organisasi karena mereka merasa harus melakukan hal tersebut.

Komitmen organisasi menurut Allen dan Meyer (1991) adalah suatu kualitas yang diinginkan yang harus dipelihara di kalangan karyawan. Dalam hal ini harus dilihat hal-hal yang dapat mempengaruhi komitmen seseorang. Cherrington (1994) mengidentifikasikan beberapa faktor yang kemudian dirangkum dalam 4 kategori:

1. Faktor personal, dimana komitmen organisasi secara general lebih besar antara karyawan yang telah tua dan lama bekerja dalam organisai. Mereka yang mempunyai nilai kerja intrinsik lebih mempunyai komitmen. Dalam kelompok, karyawan wanita cenderung untuk lebih berkomitmen terhadap perusahaan dibandingkan karyawan laki-laki. Karyawan yang berpendidikan rendah cenderung untuk mempunyai komitmen lebih tinggi daripada karyawan yang berpendidikan tinggi.

2. Karakteristik peran, dimana komitmen akan cenderung lebih kuat bagi karyawan yang memiliki enriched jobs dan pekerjaan yang melibatkan tingkatan yang rendah dari konflik peran dan ambiguitas.

3. Karakteristik struktural, komitmen akan lebih kuat pada karyawan yang berada dalam organisasi yang terdesentralisasi dan dalam kerjasama antara pemilik kerja dimana karyawan tersebut lebih terlibat dalam pembuatan keputusan organisasi.

4. Pengalaman kerja, komitmen akan kuat untuk karyawan dengan pengalama kerja yang menyenangkan, seperti sikap positif dalam kelompok seseorang terhadap orang lain, perasaan bahwa organisasi dapat diandalkan untuk memenuhi komitmennya terhadap personil yang ada di dalamnya dan perasaan bahwa individu yang ada dalam organisasi merupakan hal yang penting bagi organisasi.

Kunci utama dalam komitmen adalah bagaimana perusahaan fokus terhadap nilai-nilai dasar dalam proses kualitas kehidupan kerja. Kualitas kehidupan kerja tersebut sangat berpengaruh meskipun belum banyak perusahaan yang mengadopsi komitmen organisasional sebagai budaya. Penelitian Fields dan Thacker (1992) menunjukkan bahwa suksesnya impelentasi program kualitas kehidupan kerja secara keseluruhan berdampak positif terhadap 
komitmen pekerja baik terhadap perusahaan. Sementara penelitian Zin (2004) menunjukkan bahwa untuk meningkatkan komitmen organisasional perusahaan harus mengembangkan kualitas kehidupan kerja dengan memberikan kesempatan bagi karyawan untuk mengembangkan diri melalui program pelatihan dan berpartisipasi dalam setiap pengambilan keputusan yang berhubungan dengan pekerjaan mereka.

\section{Kinerja}

Prawirosentono dalam Sutrisno (2010:170) Kinerja adalah hasil kerja yang dapat dicapai oleh seseorang atau sekelompok orang dalam suatu organisasi, sesuai dengan wewenang dan tanggung jawab masing-masing, dalam rangka upaya mencapai tujuan organisasi bersangkutan secara legal, tidak melanggar hukum, dan sesuai dengan moral maupun etika.

Miner dalam Sutrisno (2010:170), kinerja adalah bagaimana seseorang diharapkan dapat berfungsi dan berperilaku sesuai dengan tugas yang telah dibebankan kepadanya. Setiap harapan mengenai bagaimana seseorang harus berperilaku dalam melaksanakan tugas, berarti menunjukkan suatu peran dalam organisasi. Suatu organisasi, baik organisasi pemerintah maupun organisasi privat dalam mencapai tujuan yang ditetapkan harus melalui sarana dalam bentuk organisasi yang digerakkan oleh sekelompok orang yang berperan aktif sebagai pelaku (actors) dalam upaya mencapai tujuan lembaga atau organisasi bersangkutan.

Irianto dalam Sutrisno (2010:171) Mengemukakan kinerja pegawai adalah prestasi yang diperoleh seseorang dalam melakukan tugas. Keberhasilan organisasi tergantung pada kinerja para pelaku organisasi bersangkutan.Oleh karena itu, setiap unit kerja dalam suatu organisasi harus dinilai kinerjanya, agar kinerja sumber daya manusia yang terdapat dalam unit-unit dalam suatu organisasi tersebut dapat dinilai secara objektif.

\section{Faktor Yang Mempengaruhi Kinerja}

Perusahaan sebagai suatu organisasi mempunyai tujuan yakni memperole keuntungan.Organisasi dapat beroperasi karena kegiatan atau aktivitas yang dilakukan oleh para karyawan yang ada didalam organisasi tersebut. Menurut Prawirosentono (1990) dalam Sutrisno (2010:176), faktor yang mempengaruhi kinerja pegawai adalah sebagai berikut:

\section{a. Efektif dan Efisien}

Efektivitas dari kelompok organisasi bila tujuan kelompok tersebut dapat dicapai sesuai dengan kebutuhan yang direncanakan.Sedangkan Efisien berkaitan dengan jumlah pengorbanan yang dikeluarkan dalam upaya mencapai tujuan organisasi.

b. Otoritas Dan Tanggung Jawab

Kejelasan Wewenang dan tanggung jawab setiap orang dalam suatu organisasi akan mendukung kinerja karyawan. Kinerja karyawan akan dapat terwujud bila karyawan mempunyai komitmen dengan organisasinya dan ditunjang dengan disiplin kerja yang tinggi.

c. Disiplin

Disiplin meliputi ketaatan dan hormat terhadap perjanjian yang dibuat antar perusahaan dan karyawan. Dengan demikian, bila peraturan atau ketepatan yang ada dalam perusahaan itu diabaikan atau sering dilanggar, maka karyawan mempunyai disiplin yang buruk.

d. Inisiatif

Inisiatif seseorang berkaitan dengan daya pikir, kreativitas, dalam bentuk ide untuk merencanakan sesuatu yang berkaitan dengan tujuan organisasi. Inisatif karyawan yang ada didalam organisasi merupakan daya dorong kemajuan yang akhirnya akan mempengaruhi kinerja.

Kinerja seorang pegawai akan lebih baik apabila

a. Mempunyai keahlian tinggi

b. Kesediaan untuk bekerja

c. Lingkungan kerja yang mendukung

d. Adanya imbalan yang layak.

Menurut Minner (1990) dalam Sutrisno (2010:172) mengemukakan secara umum dapat dinyatakan empat aspek dari kinerja, yaitu :

1 .Kualitas yang dihasilkan

2 .Kuantitas yang dihasilkan

3. Waktu kerja

4. Kerja sama

Adapun indikator dari kinerja pegawai menurut Nawawi (2006:66) adalah sebagai berikut :

1. Kualitas yaitu kualitas kerja yang dicapai berdasarkan syarat-syarat kesesuaian dan kesiapannya. Hal ini meliputi; hasil kerja pegawai sesuai dengan standar kualitas atau mutu yang ditetapkan oleh organisasi, hasil kerja pegawai hanya sedikit yang mengalami kesalahan.

2. Kuantitas yaitu jumlah kerja yang dihasilkan dalam suatu periode waktu yang telah 
ditentukan. Hal ini meliputi; keberhasilan mencapai standar kuantitas kerja yang telah ditetapkan organisasi, hasil kerja pegawai sering melebihi jumlah target yang telah ditetapkan organisasi.

3. Ketepatan waktu yaitu kesesuian waktu yang telah direncanakan untuk menyelesaikan suatu pekerjaan.

4. Kehadiran yaitu kesadaran dan dapat dipercaya dalam hal kehadiran dan penyelesaian pekerjaan. Hal ini meliputi; selalu datang tepat waktu di tempat kerja, dan tidak pernah absen tanpa alasan yang jelas.

5. Kemampuan bekerjasama kemampuan seorang tenaga kerja untuk bekerja bersama dengan orang lain dalam menyelesaikan suatu tugas dan pekerjaan yang telah ditetapkan sehingga mencapai daya guna dan hasil guna yang sebesar-besarnya.

\section{Penilain Kinerja}

Penilaian kinerja merupakan salah satu faktor yang penting dalam sebuah organisasi. Pengertian penilaian (assessment) adalah penerapan berbagai cara dan penggunaan berbagai alat penilain untuk memperoleh informasi tentang sejauh mana hasil belajar atau pencapaian target dari rangkaian kemampuan.

Rivai (2006:309) mengungkapakan bahwa penilaian kinerja mengacu pada suatu system formal dan terstruktur yang digunakan un tuk mengukur, menialai, dan mempengaruhi sifatsifat yang berkaitan dengan pekerjaan, perilaku, dan hasil, termasuk tingkat ketidakhadiran. Dengan demikian penilaian prestasi adalah merupakan hasil kerja pegawai dalam lingkup tanggungjawabnya.

Prosedur penilaian kinerja menurut Dessler, (2003:216) meliputi; (1) penetapan standar kinerja; (2) penilaian kinerja aktual karyawan dalam hubungannya dengan standarstandar yang ada; dan (3) memberi umpan balik kepada karyawan dengan tujuan memotivasi orang tersebut untuk menghilangkan kemerosotan kinerja atau terus berkinerja lebih tinggi lagi.

Dengan demikian kinerja adalah keseluruhan pelaksanaan aktifitas jasmani dan rohani yang dilakukan oleh manusia untuk mencapai tujuan tertentu atau mangandung suatu maksud tertentu, terutama yang berhubungan dengan kelangsungan hidupnya.

Penilaian kinerja

(performance

appraisal) menurut Simamora (2004:338), adalah proses yang dipakai organisasi untuk mengevaluasi pelaksanaan kerja individu karyawan. Dalam penilaian kinerja dinilai konstribusi pegawai kepada organisasi selama periode waktu tertentu.

Umpan balik kinerja memungkinkan pegawai mengetahui seberapa baik mereka bekerja jika dibandingkan dengan standar organisasi. Apabila dilakukan secara benar, para pegawai, penyedia mereka, departemen sumber daya manusia, dan akhirnya organisasi bakal diuntungkan dengan pemastian bahwa upaya individu memberikan konstribusi kepada fokus strategi organisasi.

\section{Manfaat Penilaian Kinerja}

Penilaian kinerja dalam rangka pengembangan sumber daya manusia adalah penting artinya, mengingat bahwa dalam kehidupan organisasi setiap karyawan, sebagai sumber daya ingin mendapatkan penghargaan dan perlakuan secara adil dari pimpinan organisasi yang bersangkutan.

Adapun manfaat penilaian kinerja dalam suatu organisasi antara lain adalah :

1. Peningkatan prestasi kerja

2. Kesempatan kerja yang adil

3. Kebutuhan pendidikan dan pelatihan.

4. Penyesuaian kompensasi

5. Keputusan promosi dan demosi

6. Kesalahan-kesalahan desain pekerjaan

\section{Hubungan antara Kompensasi dan Kinerja}

Kompensasi menjadi salah satu faktor utama kepegawaian karena pemberian kompensasi akan mempengaruhi kinerja karyawan, seperti pendapat yang disampaikan Mangkunegara (2009 :51) yang mengatakan bahwa kompensasi yang diberikan kepada pegawai sangat berpengaruh pada tingkat kepuasan kerja dan motivasi kerja, serta kinerjanya. Adanya sistem kompensasi yang baik pada suatu perusahaan diharapkan dapat meningkatkan kinerja para karyawan. Apabila perusahaan memberikan tambahan kompensasi pada karyawan, maka karyawan cenderung akan berusaha untuk meningkatkan kinerjanya. Jika karyawan merasa imbalan yang diterimanya telah sebanding dengan kontribusi yang diberikannya kepada perusahaaan, maka karyawan akan berusahan untuk mempertahankan dan bahkan meningkatkan kinerjanya dikemudian hari. Namun apabila karyawan merasa kompensasi yang diperolehnya kurang sesuai dengan apa yang telah diberikan kepada perusahaan, maka 
karyawan cenderung tidak mau untuk berusaha meningkatkan kinerjanya.

Mahmudi (2005) menyatakan bahwa kompensasi yang tinggi menuntut prestasi, kompetensi dan kualitas yang tinggi. Dengan adanya pemberian kompensasi yang tinggi dari perusahaan maka diharapkan karyawan memiliki kinerja yang tinggi.

\section{Hubungan antara Pengalaman Kerja dan Kinerja}

Pengalaman merupakan suatu proses pembelajaran dan pertambahan perkembangan potensi bertingkah laku baik dari pendidikan formal maupun non formal atau bisa diartikan sebagai suatu proses yang membawa seseorang kepada suatu pola tingkah laku yang lebih tinggi. Suatu pembelajaran juga mencakup perubahaan yang relatif tepat dari perilaku yang diakibatkan pengalaman, pemahaman dan praktek (Knoers \& Haditono, 1999).

$$
\text { Pengalaman kerja seseorang }
$$
menunjukkan jenis-jenis pekerjaan yang pernah dilakukan seseorang dan memberikan peluang yang besar bagi seseorang untuk melakukan pekerjaan dan mencapai kinerja yang lebih baik. Semakin luas pengalaman kerja seseorang, semakin trampil melakukan pekerjaan dan semakin sempurna pola berpikir dan sikap dalam bertindak untuk mencapai tujuan yang telah ditetapkan (Abriyani Puspaningsih, 2004). Johnstone et al. (2002) menemukan sebuah studi yang memberikan bukti bahwa pekerja berpengalaman bekerja lebih baik karena mereka memiliki dasar pengetahuan yang lebih besar untuk menarik dari dan lebih mahir mengorganisir pengetahuan mereka.

\section{Hubungan antara Komitmen Organisasi dan Kinerja}

Komitmen organisasional didefinisikan sebagai"The degree to which an employee identifies with aparticular organization and its goals, and wishes to maintain membership in the organization" (Robbins,2003). Selanjutnya, Porter et al. (1973) dalam Tobing (2009) mendefinisikan komitmen organisasional sebagai kekuatan relatif individu terhadap suatu organisasi dan keterlibatannya dalam organisasi tertentu, yang di cirikan oleh tiga faktor psikologis: (1) Keinginan yang kuat untuk tetap menjadi anggota organisasi tertentu, (2) Keinginan untuk berusaha sekuat tenaga demi organisasi dan (3) Kepercayaan yang pasti dan penerimaan terhadap nilai-nilai dan tujuan organisasi.

Komitmen organisasi pegawai tidak akan tumbuh dengan sendirinya, ada hubungan yang signifikan antara komitmen dan kinerja, apabila komitmen organisasi baik yang tinggi maupun yang rendah akan berdampak pada: (1) Pegawai; misalnya terhadap perkembangan kinerja dan karier pegawai di organisasi; (2) Organisasi; pimpinan yang berkomitmen tinggi pada organisasi akan menimbulkan kinerja organisasi yang tinggi, tingkat absensi berkurang, loyalitas pegawai dan sebagainya.

Somers \& Birnbaum (1998) dalam Zulham (2008) juga membuktikan pengaruh berbagai konstruk pekerjaan yang berkaitan dengan komitmen terhadap kinerja. Kartika (2010) menunjukan bahwa komitmen organisasional berpengaruh positif dan signifikan terhadap kinerja pegawai.

Angel dan Perry (1981) dalam Zulham (2008) mengemukakan bahwa komitmen organisasi yang kuat akan mendorong para individu untuk berusaha lebih keras dalam mencapai tujuan organisasi. Sehingga komitmen yang tinggi menjadikan individu lebih mementingkan organisasi daripada kepentingan pribadi dan berusaha menjadikan organisasi menjadi lebih baik lagi. Komitmen organisasi yang tinggi akan meningkatkan kinerja yang tinggi pula (Randall,1990) dalam Nouri dan Parker (1996). Penelitian yang dilakukan oleh Hakim (2006) menyimpulkan bahwa komitmen organisasi mempunyai pengaruh yang positif terhadap kinerja pegawai. Hal ini juga didukung oleh penelitian yang dilakukan Diana Tobing (2009) yang menguji pengaruh komitmen organisasi tehadap kinerja pegawai menunjukkan bahwa komitmen organisasi berpengaruh positif dan signifikan terhadap kinerja pegawai. Hal ini berarti bahwa dengan adanya peningkatan komitmen organisasi dari pegawai maka kinerja pegawai akan meningkat.

\section{METODE PENELITIAN Populasi}

Arikunto (1996:115) populasi adalah keseluruhan subjek penelitian, apabila peneliti ingin meneliti semua elemen yang ada dalam wilayah penelitian maka penelitiannya merupakan populasi studi atau juga disebut populasi studi sensus. Sedangkan Sugiyono (2003) menyebutkan bahwa sampel jenuh atau sensus adalah teknik 
penentuan sampel bila semua populasi digunakan sebagai sampel. Hal ini dilakukan bila jumlah populasi relative kecil. Dengan demikian, sampel dalam penelitian ini mengambil seluruh populasi pegawai pada Dinas Pekerjaan Umum Daerah Kabupaten Sigi yang ada berjumlah 57 orang, penulis yang juga merupakan pegawai pada lokasi penelitian tidak terlibat sebagai subjek untuk menjaga objektifitas penelitian. Dengan demikian maka sampel dalam penelitian ini adalah 56 orang responden (sampel jenuh).

\section{Defenisi Operasional Variabel}

Variabel-variabel yang akan dianalisis dalam penelitian ini diklasifikasikan sebagai berikut:

1. Kompensasi (Independen Variabel)

Definisi kompensasi adalah Semua pendapatan yang berbentuk uang, barang langsung atau tidak langsung yang diterima pegawai pada Dinas Pekerjaan Umum Daerah Kabupaten Sigi sebagai imbalan atau jasa yang diberikan kepada organisasi. Dimensi kompensasi yang relevan menurut Mondy et al., (1993), yakni:

a. Kompensasi finansial langsung, terdiri dari bayaran (pay) yang diperoleh seseorang dalam bentuk gaji, upah, bonus dan komisi.

b. Kompensasi finansial tidak langsung atau disebut juga dengan tunjangan (meliputi imbalan finansial yang tidak tercakup dalam kompensasi langsung).

c. Kompensasi non finansial adalah kepuasan yang diperoleh seseorang dari pekerjaan itu sendiri, atau dari lingkungan psikologis dan atau fisik dimana orang tersebut bekerja. Meliputi dari kepuasan yang didapat dari pelaksanaan tugas-tugas yang bermakna yang berhubungan dengan pekerjaan. Contoh bentuk kompensasi non finansial adalah tugas yang menarik, tantangan, tanggung jawab, peluang atau pengakuan, perasaan akan pencapaian, peluang akan promosi.

2. Pengalaman kerja (Independen Variabel)

Definisi pengalaman kerja adalah ukuran tentang lama waktu atau masa kerja yang telah ditempuh pegawai pada Dinas Pekerjaan Umum Daerah Kabupaten Sigi, dapat memahami tugastugas suatu pekerjaan dan telah melaksanakannya dengan baik. Dimensi yang relevan dari pengalaman kerja dari pendapat Foster (2001) yaitu;

a. Lama waktu / masa kerja
Ukuran tentang lama waktu atau masa kerja yang telah ditempuh seseorang dapat memahami tugas-tugas suatu pekerjaan dan telah melaksanakan dengan baik.

b. Tingkat pengetahuan dan keterampilan yang merujuk pada konsep, prinsip, prosedur, kebijakan, atau informasi lain yang dibutuhkan oleh karyawan. Pengetahuan juga mencakup kemampuan untuk memahami dan menerapkan informasi pada tanggung jawab pekerjaan. Sedangkan keterampilan merujuk pada kemampuan fisik yang dibutuhkan untuk mencapai atau menjalankan suatu tugas atau pekerjaan.

c. Penguasaan terhadap pekerjaan dan peralatan Tingkat penguasaan seseorang dalam pelaksanaan aspek-aspek teknik peralatan dan teknik pekerjaan.

3. Komitmen Organisasi (Independen Variabel) Definisi komitmen organisasi dalam penelitian ini adalah adalah sikap yang merefleksikan loyalitas pegawai Dinas Pekerjaan Umum Daerah Kabupaten Sigi pada organisasi dan proses berkelanjutan di mana pegawai Dinas Pekerjaan Umum Daerah Kabupaten Sigi mengekspresikan perhatiannya terhadap organisasi dan keberhasilan serta kemajuan yang berkelanjutan, Variabel komitmen organisasi diadopsi dari pendapat Allen dan Meyer (1991) yakni :

a. Affective commitment, didefinisikan sebagai sampai derajad manakah seorang individu terikat secara psikologis pada organisasi yang mempekerjakan melalui perasaan seperti loyalitas, terikat dan sepakat dengan tujuan organisasi.

b. Continuance commitment adalah suatu keadaan dimana karyawan merasa membutuhkan untuk tetap tinggal, dimana mereka berfikir bahwa meninggalkan perusahaan akan sangat merugikan bagi mereka.

c. Normative commitment, adalah suatu perasaan dari karyawan tetang kewajiban untuk bertahan dalam organisasi..

4. Kinerja Pegawai (Dependen Variabel)

Definisi kinerja pegawai dalam penelitian ini adalah hasil kerja yang dapat dicapai oleh pegawai atau sekelompok pegawai pada Dinas Pekerjaan Umum Daerah Kabupaten Sigi, sesuai dengan wewenang dan tanggung jawab masingmasing, dalam rangka upaya mencapai tujuan organisasi bersangkutan secara legal, tidak 
melanggar hukum, dan sesuai dengan moral maupun etika. Kinerja pegawai dalam penelitian ini dijustifikasi dari dimensi yang dikemukan oleh Nawawi (2006) yaitu:
a. Kualitas
b. Kuantitas
c. Ketepatan waktu
d. Kehadiran
e. Kemampuan

\section{Uji Validitas}

Validitas adalah hasil penelitian yang jika terdapat kesamaan antara data yang terkumpul dengan data sesungguhnya (Sugiyono, 2006).

Validitas adalah suatu ukuran yang menunjukkan tingkat kevalidan atau kesahihan suatu instrumen. Suatu instrumen yang valid mempunyai validitas tinggi dan sebaliknya bila tingkat validitasnya rendah maka instrumen tersebut kurang valid. Sebuah instrumen dikatakan valid apabila mampu mengukur apa yang hendak diukur/diinginkan. Sebuah instrumen dikatakan valid apabila dapat mengungkap data dari variabel yang diteliti.

Validitas dapat diketahui dengan cara membandingkan nilai Corrected item-Total Correlation dengan nilai r-kritis sesuai kriteria. Menurut Sugiyono (2006: 124), bahwa bilamana koefisien antara skor suatu indikator dengan skor total seluruh indikator adalah positif dan lebih besar $0,3 \quad(r \geq 0,3)$ maka instrumen tersebut dianggap valid. Dimana perhitungannya untuk melihat validitas instrumen menggunakan bantuan program SPSS 16.0.

\section{Uji Reliabilitas}

Salah satu ciri instrumen ukur yang berkualitas baik adalah reliabel (reliable), yaitu bila terdapat kesamaan data dalam waktu yang berbeda (Sugiyono, 2006). Koefisien reliabilitas berada dalam rentang angka dari 0 sampai dengan 1,00 .

Uji reliabilitas internal diperoleh dengan menganalisis data dari satu kali pengetesan. Salah satu uji reliabilitas internal yang populer adalah formula koefisien alpha $(\alpha)$. Instrumen dikatakan reliabel, jika besarnya nilai koefisien Alpha Cronbach di atas 0,60, berarti memenuhi syarat minimum (Sugiyono, 2006). Dimana perhitungannya untuk melihat reliabilitas instrumen menggunakan bantuan program SPSS 16.0. Hasil analisis dengan bantuan program SPSS
16.0 yang telah dilakukan terhadap variabel kompensasi, pengalaman kerja, komitmen organisasi dan kinerja pegawai dapat dilihat pada tabel berikut:

Tabel 1. Hasil Uji Reliabilitas

\begin{tabular}{|l|c|c|}
\hline \multicolumn{1}{|c|}{ Variabel } & $\begin{array}{c}\text { Alpha } \\
\text { Cronbach }\end{array}$ & Keterangan \\
\hline Kompensasi $\left(\mathrm{X}_{1}\right)$ & 0,815 & Reliable \\
\hline Pengalaman Kerja $\left(\mathrm{X}_{2}\right)$ & 0,925 & Reliable \\
\hline Komitmen Organisasi $\left(\mathrm{X}_{3}\right)$ & 0,856 & Reliable \\
\hline Kinerja Pegawai $(\mathrm{Y})$ & 0,900 & Reliable \\
\hline
\end{tabular}

\section{Uji Asumsi Klasik}

1. Uji Normalitas.

Model regresi yang baik adalah distribusi data normal atau mendekati normal. Menurut Ghozali (2005;108) deteksi normalitas dilakukan dengan melihat penyebaran data (titik) pada sumbu diagonal dari grafik.

Dengan menggunakan bantuan program statistik hasil uji normalitas data pada penelitian ini dapat dilihat pada grafik (gambar) di bawah ini:

\section{Gambar 1. Hasil Uji Normalitas}

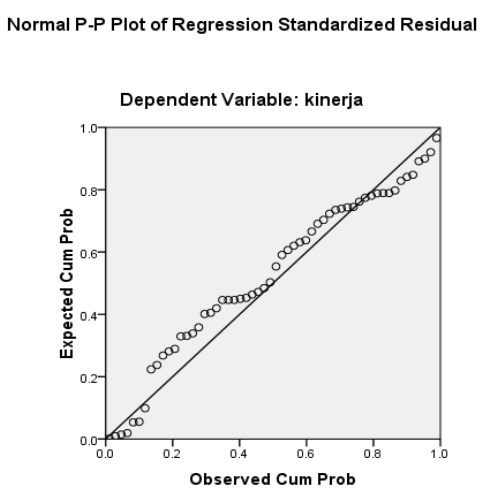

Pada gambar tersebut memperlihatkan bahwa sebaran data mengikuti garis diagonal. Berdasarkan hal tersebut, maka dapat disimpulkan bahwa data yang digunakan dalam analisis regresi ini terdistribusi dengan normal.

2. Uji Multikolinearitas.

Model regresi yang baik seharusnya tidak terjadi korelasi diantara variabel independen. Menurut Ghozali (2005;105): untuk mengetahuinya adanya multikolinearitas 
dengan melihat nilai Variance Inflation Factor (VIF). Nilai toleran yang lebih besar dari 0,10 atau nilai VIF lebih kecil dari 10, maka terjadi multikolinearitas. Hasil uji multikolinearitas dengan menggunakan VIF dan tolerance seperti pada tabel berikut:

Tabel 2. Hasil Uji Multikolinearitas

\begin{tabular}{|c|l|c|c|}
\hline \multirow{2}{*}{ No } & \multirow{2}{*}{ Variabel } & \multicolumn{2}{c|}{$\begin{array}{c}\text { Collinearity } \\
\text { Statistics }\end{array}$} \\
\cline { 3 - 4 } & & Tolerance & VIF \\
\hline 1 & Kompensasi $\left(\mathrm{X}_{1}\right)$ & 0,807 & 1,239 \\
\hline 2 & Pengalaman Kerja $\left(\mathrm{X}_{2}\right)$ & 0,936 & 1,068 \\
\hline 3 & Komitmen Organisasi $\left(\mathrm{X}_{3}\right)$ & 0,774 & 1,291 \\
\hline
\end{tabular}

3. Uji Heteroskedastisitas.

Uji heterokedastisitas bertujuan untuk mengetahui apakah variabel pengganggu (distrubance error) mempunyai varians konstan. Uji ini juga untuk menguji apakah dalam model regresi terjadi ketidaksamaan variance dari residual satu pengamatan ke pengamatan lainnya.

Menurut Imam Ghozali (2005; 105) untuk menguji asumsi ini dilakukan dengan melihat grafik scaterplot antara nilai prediksi variabel terikat (ZPRED) dengan variabel bebas (SRESID) dengan residualnya.

Hasil uji heterokedastisitas dari model regresi yang terbentuk tersaji pada gambar berikut:

Gambar 2. Hasil Uji Heteroskedastisitas

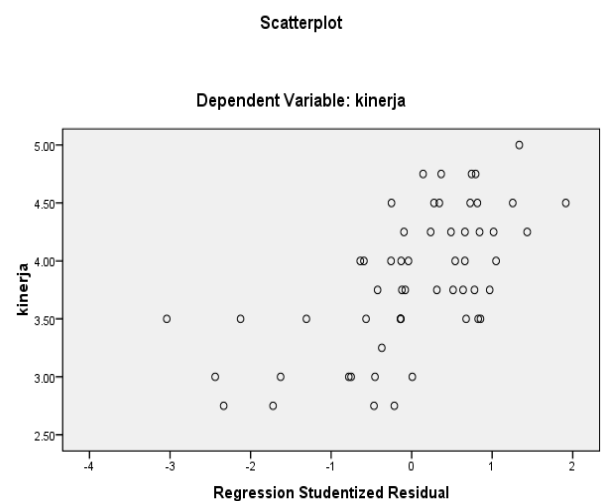

Berdasarkan Gambar di atas terlihat titiktitik menyebar secara acak, tidak membentuk sebuah pola tertentu yang jelas, serta tersebar baik di atas maupun dibawah angka 0 pada sumbu Y. Hal ini memberi makna bahwa persamaan regresi memenuhi asumsi heteroskedastisitas.

\section{HASIL DAN PEMBAHASAN \\ Hasil Pengujian Regresi}

Sesuai hasil analisis Regresi Linear Berganda dengan menggunakan bantuan komputer SPSS For Wind Release 16.0 diperoleh hasil-hasil penelitian dari 56 orang responden dengan dugaan pengaruh ketiga variabel independen (kompensasi, pengalaman kerja dan komitmen organisasi) terhadap kinerja pegawai pada Dinas Pekerjaan Umum Daerah Kabupaten Sigi dapat diketahui hasil perhitungan sebagai berikut:

Tabel 3. Hasil Uji Regresi

\begin{tabular}{|c|c|c|c|}
\hline & Variabel & $\begin{array}{c}\text { Unstandardi } \\
\text { zed } \\
\text { Coefficients }\end{array}$ & Sig \\
\hline & Constanta & 1,582 & \\
\hline $\mathrm{X}_{1}$ & Kompensasi & 0,245 & 0,000 \\
\hline $\mathrm{X}_{2}$ & Pengalaman Kerja & 0,244 & 0,000 \\
\hline $\mathrm{X}_{3}$ & $\begin{array}{l}\text { Komitmen } \\
\text { Organisasi }\end{array}$ & 0,195 & 0,001 \\
\hline $\begin{array}{l}\text { R } \\
\text { F H } \\
\text { R S } \\
\text { Sig }\end{array}$ & $\begin{array}{ll} & ; 0,784 \\
\text { ung } & ; 27,626 \\
\text { uare } & ; 0,614 \\
& ; 0,000 \\
\end{array}$ & & \\
\hline
\end{tabular}

Model regresi yang diperoleh dari tabel diatas adalah:

$$
\mathrm{Y}=-\mathbf{1 . 5 8 2}+\mathbf{0 . 2 4 5 X 1}+\mathbf{0 . 2 4 4 X 2}+\mathbf{0 . 1 9 5 X 3}
$$

Persamaan diatas menunjukkan, variabel independen yang dianalisis berupa variabel (X1, $\mathrm{X} 2$ dan X3) memberi pengaruh terhadap variabel independen (Y). Dari persamaan di atas dapat dijelaskan:

1. Untuk nilai constanta sebesar 1.582 berarti kinerja pegawai pada Dinas Pekerjaan Umum Daerah Kabupaten Sigi sebelum adanya variabel independen adalah sebesar 1.582.

2. Kompensasi (X1) dengan koefisien regresi 0.245 ini berarti terjadi pengaruh yang positif antara kompensasi dan kinerja pegawai pada Dinas Pekerjaan Umum Daerah Kabupaten Sigi. Artinya semakin sesuai kompensasi pegawai yang ada pada Dinas Pekerjaan Umum Daerah Kabupaten Sigi maka akan menaikkan kinerja pegawai Negeri Sipil.

3. Pengalaman Kerja $\left(\mathrm{X}_{2}\right)$ dengan koefisien regresi 0,244 ini berarti terjadi pengaruh yang positif antara pengalaman kerja dan kinerja 
pegawai. Artinya semakin berpengalaman pegawai dalam bekerja pada Dinas Pekerjaan Umum Daerah Kabupaten Sigi maka akan menaikkan kinerja pegawai Negeri Sipil.

4. Komitmen Organisasi $\left(\mathrm{X}_{3}\right)$ dengan koefisien regresi 0,195 ini berarti terjadi pengaruh yang positif antara komitmen organisasi dengan kinerja pegawai. Arinya semakin berkomitmen pegawai terhadap organisasi dalam bekerja pada Dinas Pekerjaan Umum Daerah Kabupaten Sigi maka akan menaikkan kinerja pegawai Negeri Sipil.

Selanjutnya berdasarkan tabel diatas dari hasil perhitungan diperoleh Fhitung $=27.626$ dan nilai Sig F $(0.000)<0,05$. Dengan demikian dapat dinyatakan bahwa secara serempak variabel kompensasi, pengalaman kerja dan komitmen organisasi berpengaruh signifikan terhadap variabel kinerja pegawai pada Dinas Pekerjaan Umum Daerah Kabupaten Sigi. Dengan demikian maka hipotesis pertama berdasarkan hasil uji-F ternyata terbukti.

\section{Pengujian Hipotesis Kedua}

Untuk variabel kompensasi, hasil perhitungannya menunjukkan bahwa nilai koefisien regresi sebesar 0.245 , sementara nilai signifikasi t sebesar 0,000. Dengan demikian nilai Sig $t<0,05$ pada taraf kepercayaan $95 \%$. Sehingga dapat dinyatakan bahwa variabel kompensasi berpengaruh positif dan signifikan terhadap kinerja pegawai pada Dinas Pekerjaan Umum Daerah Kabupaten Sigi, berdasarkan hasil uji-t ternyata terbukti.

\section{Pengujian Hipotesis Ketiga}

Untuk variabel pengalaman kerja, hasil perhitungannya menunjukkan bahwa nilai koefisien regresi sebesar 0.244 , sementara nilai signifikasi t sebesar 0,000. Dengan demikian nilai Sig $\mathrm{t}<0,05$ pada taraf kepercayaan 95\%. Sehingga dapat dinyatakan bahwa variabel pengalaman kerja berpengaruh positif dan signifikan terhadap kinerja pegawai pada Dinas Pekerjaan Umum Daerah Kabupaten Sigi, berdasarkan hasil uji-t ternyata terbukti.

\section{Pengujian Hipotesis Keempat}

Untuk variabel komitmen organisasi, hasil perhitungannya menunjukkan bahwa nilai koefisien regresi sebesar 0.195 , sementara nilai signifikasi t sebesar 0,001. Dengan demikian nilai
Sig $\mathrm{t}<0,05$ pada taraf kepercayaan $95 \%$. Sehingga dapat dinyatakan bahwa variabel komitmen organisasi berpengaruh positif dan signifikan terhadap kinerja pegawai pada pada Dinas Pekerjaan Umum Daerah Kabupaten Sigi, berdasarkan hasil uji-t ternyata terbukti.

\section{Pembahasan}

Pengaruh Kompensasi, Pengalaman Kerja dan Komitmen Organisasi terhadap Kinerja PNS Pada Dinas Pekerjaan Umum Daerah Kabupaten Sigi.

Berdasarkan hasil analisis statistik diperoleh nilai signifikansi $(0,000)$ lebih kecil dari nilai alpha $5 \% \quad(0,000<0,05)$. Berdasarkan hal tersebut dapat diketahui bahwa kompensasi, pengalaman kerja dan komitmen organisasi secara simultan berpengaruh signifikan terhadap Kinerja PNS pada Dinas Pekerjaan Umum Daerah Kabupaten Sigi. Keadaan ini menunjukkan bahwa PNS Dinas Pekerjaan Umum Daerah Kabupaten Sigi memiliki pemahaman dan pengetahuan tentang penerapan kompensasi, pengalaman kerja dan komitmen organisasi yang baik dalam pelaksanaan tugas pokok dan fungsinya sehingga akan membantu para pegawai untuk meningkatkan kinerjanya.

Keadaan ini juga menunjukkan bahwa ketika kompensansi pegawai di Dinas Pekerjaan Umum Daerah Kabupaten Sigi ditingkatkan yang ditunjang dengan pengalaman kerja dan komitmen organisasi yang tinggi, maka akan mendorong peningkatan kinerja PNS pada Dinas Pekerjaan Umum Daerah Kabupaten Sigi.

Pengaruh Kompensasi terhadap Kinerja PNS Pada Dinas Pekerjaan Umum Daerah Kabupaten Sigi.

Berdasarkan hasil uji statistik menunjukkan bahwa secara parsial variabel kompensasi memberikan pengaruh yang positip dan signifikan terhadap Kinerja PNS pada Dinas Pekerjaan Umum Daerah Kabupaten Sigi. Hasil ini memberikan gambaran bahwa PNS Dinas Pekerjaan Umum Daerah Kabupaten Sigi menilai bahwa kompensasi yang diberikan yang terdiri dari kompensasi finansial dan kompensasi non finansial telah sesuai dengan yang diharapkan pegawai, dan sekaligus menjadi motor penggerak dalam meningkatkan kinerja pegawai di Dinas Pekerjaan Umum Daerah Kabupaten Sigi.

Hasil uji statistik ini diperkuat dengan hasil analisis distribusi frekuensi tanggapan responden/pegawai Dinas Pekerjaan Umum Daerah Kabupaten Sigi pada variabel kompensasi 
yang terdiri atas kompensasi finansial dan kompensasi non finansial menunjukkan penilaian yang sangat tinggi, yang artinya PNS Dinas Pekerjaan Umum Daerah Kabupaten Sigi mengakui bahwa mereka telah menerima gaji tepat waktu, memiliki kartu asuransi, menggunakan kartu asuransi kesehatan, namun pegawai mengakui bahwa bonus yang mereka terima belum sepenuhnya sesuai dengan volume pekerjaan, PNS juga mengakui bahwa mereka sangat menyukai pekerjaannya dan berkesempatan memiliki peluang untuk dipromosikan. Secara umum ketika kompensasi PNS Dinas Pekerjaan Umum Daerah Kabupaten Sigi semakin ditingkatkan maka akan mendorong pegawai untuk selalu meningkatkan kinerjanya.

Hasil penelitian ini konsisten dengan pendapat Mangkunegara (2009:51) yang mengatakan bahwa kompensasi yang diberikan kepada pegawai sangat berpengaruh pada kinerjanya. Adanya sistem kompensasi yang baik pada suatu perusahaan diharapkan dapat meningkatkan kinerja para pegawai. Apabila perusahaan memberikan tambahan kompensasi pada pegawai, maka pegawai cenderung akan berusaha untuk meningkatkan kinerjanya. Jika pegawai merasa imbalan yang diterimanya telah sebanding dengan kontribusi yang diberikannya kepada perusahaaan, maka karyawan akan berusahan untuk mempertahankan dan bahkan meningkatkan kinerjanya dikemudian hari.

Hasil penelitian ini sejalan penelitian yang dilakukan oleh Lamidu (2015) dan Rizaldy (2014) yang menyatakan bahwa kompensasi berpengaruh signifikan terhadap kinerja pegawai.

Pengaruh Pengalaman Kerja terhadap Kinerja PNS Pada Dinas Pekerjaan Umum Daerah Kabupaten Sigi

Berdasarkan hasil uji statistik menunjukkan bahwa secara parsial variabel pengalaman kerja memberikan pengaruh yang signifikan terhadap Kinerja PNS. Hasil ini memberikan gambaran bahwa PNS Dinas Pekerjaan Umum Daerah Kabupaten Sigi memandang bahwa pengalaman kerja PNS merupakan penentu atas meningkatnya kinerja mereka, karena menurut pegawai, Dinas Pekerjaan Umum Daerah Kabupaten Sigi merupakan instansi teknis, yang pekerjaannya membutuhkan pengalaman, artinya setiap pegawai yang bekerja akan memberikan kinerja yang maksimal ketika pekerjaan itu sudah pernah dilakukan.
Hasil distribusi frekuensi yang telah dilakukan sebelumnya memperkuat hasil analisis statistik di atas menunjukkan penilaian yang baik artinya dari segi pengalaman diperoleh PNS selama bekerja telah mampu meningkatkan kinerjanya, pegawai mengakui bahwa walaupun masih perlu ditingkatan, mereka telah memiliki ketelitian dalam bekerja, memahami pekerjaannya, menguasai pekerjaannya. PNS Dinas Pekerjaan Umum Daerah Kabupaten Sigi juga mengakui bahwa Waupun masih perlu ditingkatkan namun mereka telah memiliki keterampilan dalam bekerja dan mampu mengoperasikan peralatan. Secara umum ketika pengalaman kerja PNS Dinas Pekerjaan Umum Daerah Kabupaten Sigi bertambah maka akan mendorong pegawai meningkatkan kinerjanya.

Hasil penelitian ini sesuai dengan pendapat Puspaningsih (2004) yang menyatakan pengalaman kerja seseorang menunjukkan jenisjenis pekerjaan yang pernah dilakukan seseorang dan memberikan peluang yang besar bagi seseorang untuk melakukan pekerjaan dan mencapai kinerja yang lebih baik. Semakin luas pengalaman kerja seseorang, semakin trampil melakukan pekerjaan dan semakin sempurna pola berpikir dan sikap dalam bertindak untuk mencapai tujuan yang telah ditetapkan.

Hasil penelitian ini sejalan dengan penelitian yang dilakukan oleh Nunu (2015) yang menemukan bahwa pengalaman kerja berpengaruh signifikan terhadap kinerja pegawai.

Pengaruh Komitmen Organisasi terhadap Kinerja PNS Pada Dinas Pekerjaan Umum Daerah Kabupaten Sigi

Berdasarkan hasil uji statistik menunjukkan bahwa secara parsial variabel komitmen organisasi memberikan pengaruh yang positif dan signifikan terhadap Kinerja PNS. Hal ini menunjukkan bahwa secara parsial hasil ini memberikan gambaran bahwa PNS Dinas Pekerjaan Umum Daerah Kabupaten Sigi memandang komitmen organisasi pegawai Dinas Pekerjaan Umum Daerah Kabupaten Sigi merupakan yang menentukan meningkatnya kinerja pegawai.

Pegawai bekerja dan berusaha meningkatkan kinerjanya karena didorong oleh perasaan komitmen yang ada pada diri pegawai untuk menyelesaikan dan meningkatkan kinerjanya. Disamping itu juga, pegawai merasa bahwa hal itu merupakan bagian dari kewajibannya untuk melaksanakan tugas pokok 
dan fungsinya sebagai PNS Dinas Pekerjaan Umum Daerah Kabupaten Sigi.

Hasil analisis regresi di atas diperkuat dengan analisis distribusi frekuensi tanggapan responden yang telah dilakukan sebelumnya, tanggapan responden pada variabel komitmen organisasi yang terdiri atas affective commitment (komitmen afektif), continuance commitment (komitmen berkesinambungan) dan normative commitment (komitmen normative) menunjukkan penilaian yang baik yang artinya pegawai mengakui bahwa mereka telah memiliki loyalitas pada organisasi dan merasa terikat untuk selalu bekerja di Dinas Pekerjaan Umum Daerah Kabupaten Sigi, pegawai mengakui juga bahwa mereka merasa rugi jika meninggalkan organisasi. Secara umum ketika komitmen organisasi PNS Dinas Pekerjaan Umum Daerah Kabupaten Sigi meningkat maka akan mendorong pegawai meningkatkan kinerjanya. Hasil penelitian ini sejalan dengan pendapat Randall dalam Nouri dan Parker (1996) yang menyatakan bahwa komitmen organisasi yang tinggi akan meningkatkan kinerja yang tinggi pula.

Hasil penelitian ini sejalan dengan penelitian yang dilakukan oleh Kartika (2010) yang menemukan bahwa komitmen organisasi berpengaruh positif dan signifikan terhadap kinerja pegawai.

\section{KESIMPULAN}

\section{Kesimpulan}

Berdasarkan hasil analisis dan pembahasan, maka kesimpulan penelitian ini adalah sebagai berikut:

1. Kompensasi, pengalaman kerja dan komitmen organisasi secara simultan berpengaruh positif dan signifikan terhadap kinerja PNS pada Dinas Pekerjaan Umum Daerah Kabupaten Sigi.

2. Kompensasi berpengaruh positif dan signifikan terhadap kinerja PNS pada Dinas Pekerjaan Umum Daerah Kabupaten Sigi.

3. Pengalaman kerja berpengaruh positif dan signifikan terhadap kinerja PNS pada Dinas Pekerjaan Umum Daerah Kabupaten Sigi.

4. Komitmen organisasi berpengaruh positif dan signifikan terhadap kinerja PNS pada Dinas Pekerjaan Umum Daerah Kabupaten Sigi.

\section{Saran}

Saran yang dapat diajukan dalam penelitian ini dengan melihat hasil pembahasan penelitian adalah sebagai berikut:

1. Pada variabel kompensasi disarankan agar pimpinan perlu meningkatkan kompensasi finansial terutama pemberian Bonus harus sesuai dengan Volume Pekerjaan yang dibebankan pada Pegawai

2. Pada variabel pengalaman kerja lama waktu/masa kerja perlu diperhatikan terutama pemahaman kerja pegawai yang rendah walaupun dengan masa kerja yang lama untuk itu Pimpinan perlu memberikan Pelatihan khusus

3. Pada variabel komitmen organisasi, Pimpinan perlu memberikan pemahaman pada pegawai tentang komitmen yang berkelanjutan agar pegawai mempunyai tanggung jawab yang tinggi dan merasa dibutuhkan untuk tetap bekerja di Dinas Pekerjaan Umum Kabupaten Sigi.

\section{DAFTAR PUSTAKA}

Allen, N.J. dan J.P. Meyer. 1991. The Measurement and Antecedents of Affective, Continuance and Normative Commitment to the Organizational. Journal of Occupational Psychology. 63 (1): 1-18.

Asri, Marwan. 1986. Pengelolahan Karyawan. Yogyakarta: BPFE.

Arikunto,1996, Prosedur Penelitian Suatu Pendekatan Praktek. Jakarta: Rineka Cipta.

Brown, U.J. and Gaylor, K. 2002. Organizational Commitment in Higher. Education. Jackson State University: Mississippi.

Cherrington, David J,. 1994. Organizational Behavior : The Management of Individual and Organizational Performance, Second Edition, Allyn \& Bacon, Boston.

Dessler, Gary.2003. Human Resource Management Tenth Edition. New Jersey: Prentice Hall.

Fields, Mitchel W., and James W. Thacker,1992, Influence of Quality of Work Life on Company and Union Commitment, Academy of Management journal, 35, (2). pp 439-450.

Foster, Bill. 2001. Pembinaan untuk Peningkatan Kinerja Karyawan. PPM : Jakarta.

Ghozali, Imam. 2005. Aplikasi Analisis Multivariate Dengan Program SPSS. Cetakan Keempat. Semarang: Badan Penerbit Universitas Diponegoro. 
Hasibuan, Malayu S.P. 2005. Manajemen Sumber Daya Manusia, Edisi Revisi. Bumi Aksara, Jakarta.

Hasibuan, Malayu S.P. 2002. Manajemen Sumber Daya Manusia. Bumi Aksara.

Hakim Abdul, 2006. Reformasi Pengelolaan dan Pertanggungjawaban Keuangan Daerah. Fakultas Ekonomi UGM, Yogyakarta.

Kusjainah. 2004. Pengaruh Iklim Organisasi Terhadap Komitmen Karyawan. KOMPAK . Nomor 12, September-Desember : Hal.454 476.

Kartika, A. (2010). Pengaruh Komitmen Organisasi Dan Ketidakpastian Lingkungan dalam Hubungan Antara Partisipasi Anggaran dengan Senjangan Anggaran (Studi Empirik Pada Rumah Sakit Swasta di Kota Semarang). Jurnal Akuntansi, 39-60.

Lamidu, Ichsan. 2015. Pengaruh Kompensasi, Disiplin Kerja dan Motivasi terhadap Kinerja Pegawai Dinas Koperasi UMKM Perindustrian dan Perdagangan Kabupaten Morowali. Tesis. Program Magister Manajemen Universitas Tadulako Palu.

Luthans, Fred. 2006. Perilaku Organisasi. Penerbit Andi, Yogyakarta.

Luthans, Fred, 1995, Organizational Behaviour, Seventh Edition, McGraw Hill,. Singapore

Mangkunegara, A.A. Anwar Prabu, 2009. Evaluasi Kinerja SDM. PT. Refika Aditama, Bandung.

Mondy, R. Wayne, Robert M. Noe and Shane R. Premeaux. 1993. Human Resource Management. Fifth Edition. Massachusetts : Allyn and Bacon.

Mahmudi, 2005. Manajemen Kinerja Sektor Publik, Edisi I, Yogyakarta : Penerbit Buku UPP AMP YKPN.

Nawawi, Hadari, 2006. Evaluasi dan Manajemen Kinerja Dilingkungan Perusahaan dan industri. Yogyakarta: Gajah Madah Universty Press.

Nouri, H. dan R. J. Parker. 1996. "The Effect of Organizational Commitment on Relation Between Budgetary Participation and Budgetary Slack". Behavior Research in Accounting 8. Hal. 74-89.

Nunu, Islam Mohammad, 2015. Pengaruh Motivasi, Pengalaman Kerja dan Kepuasan Kerja terhadap Kinerja Pegawai pada Badan Perencanaan, Penelitian dan Pembangunan Daerah Kabupaten Morowali. Tesis. Program
Magister Manajemen Universitas Tadulako Palu.

Puspaningsih, Abriyani. 2004. Faktor-faktor yang berpengaruh terhadap kepuasan kerja dan kinerja manajer perusahaan manufaktur. Jurnal. Vol.8 No.1, Hal. 243-250.

Prayitno, 2003. Panduan Bimbingan dan Konseling. Dekdikbut Direktorat Pendidikan Dasar dan Menengah, Jakarta.

Robbins, S., \& Judge. (2011). Perilaku Organisasi. Jakarta: Selemba empat.

Rizaldy. 2014. Pengaruh Kompensasi, Motivasi dan Komitmen Organisasional terhadap Kinerja Karyawan Badan Kepegawaian Daerah Kota Semarang (Studi Kasus di Badan Kepegawaian Daerah Kota Semarang). RD CAESARIO. Vol. 2. No.1. Hal. 1 -15.

Ruky, Achmad S, 2001, Manajemen Penggajian dan Pengupahan Untuk Karyawan Perusahaan, Edisi Pertama, Gramedia Pustaka Utama, Jakarta.

Ranupandojo. 1984. Manajemen Personalia. Yogyakarta : BPFE.

Rivai, V., \& Ella, J. S. (2011). Manajemen Sumber Daya Manusia Untuk Perusahaan dari Teori ke Praktik. Jakarta: PT. Raja Grafindo.

Samsudin, Sadili. 2006, Manajemen Sumber Daya Manusia, cetakan ke-1 Bandung: Pustaka Setia.

Sutrisno, Edy. 2010. Manajemen Sumber Daya Manusia; Jakarta, PT Prenada Media Group.

Simamora, Henry. 2004. Manajemen Sumber Daya Manusia. Edisi Ke-3. STIE YKPN. Yogyakarta.

Sugiyono. 2006. Metode Penelitian Bisnis. CV. Alfabeta, Bandung.

Tobing, Diana Sulianti, K.L. 2009. Pengaruh Komitmen Organisasi dan Kepuasan Kerja Terhadap Kinerja Karyawan PT. Perkebunan Nusantara III di Sumatera Utara, Jurnal Manajemen dan Kewirausahaan, Vol. 11, No.20. Hal 65-70.

Zin, Razali Mat. (2004). Perception of Professional Engineers Towar Quality of Work Life and Organizational Commitment. Gajahmada International Journal of Business Vol.6 No.3, p.323-324.

Zulham Muhammad. 2008. Analisis Pengaruh Budaya Organisasi dan Etos Kerja Terhadap Kinerja Pegawai Fakultas Ekonomi Universitas Sumatera Utara Medan. Tesis, 
Sekolah Pascasarjana Universitas Sumatera Utara Medan. 